\title{
Why is it so Difficult to Implement a GST in Pakistan?
}

\author{
Ehtisham Ahmad*
}

\begin{abstract}
This paper discusses the efforts by the Government of Pakistan to implement a General Sales Tax (GST). First, a history of Pakistani tax reform efforts is presented along with the reforms recommended by the National Taxation Reforms Commission. After this, the design and implementation of the GST is discussed followed by an analysis of the political economy and provincial issues that arise in the process of implementing the GST. Finally, the paper discusses various proposals regarding the determination of the base for the GST. The paper concludes that the splitting of the GST by sectors, given the perspective that the 1930's style sales tax, is not sensible, and the Pakistani formulation is more unstable than the assignment of the GST on goods.
\end{abstract}

Keywords: Tax, reforms, GST, Pakistan.

\section{JEL Classification: H29.}

\section{Antecedents: Efforts to Reform the Tax System since the 1980s}

Since the late 1970s, Pakistan has received more advice on tax reforms from academics and international agencies than most developing countries. Indeed, an International Monetary Fund (IMF) technical assistance mission led by Vito Tanzi in the late 1970s was the first to broach the issue of value-added tax (VAT). This was seen as a mechanism to remove the distortions in a cascading system of taxes, and provide a basis for moving the tax/gross domestic product (GDP) ratio from under 14 percent (the average for developing countries in the 1980s; see Tanzi, 1987) to around 20 percent to meet spending needs to maintain an adequate level of investment and more effective public services. The analytics were refined by Ahmad and Stern (University of Warwick/LSE research project in the 1980s, and applying the insights of the optimal tax literature and the theory of reform-see in particular Ahmad and Stern, 1991) - with a general sales tax

\footnotetext{
* Senior Fellow, Center for Development Research, University of Bonn, and Asia Research Centre, London School of Economics. The views are personal and do not necessarily represent the views of any agency that I have been associated with.
} 
(GST) featuring as the main innovation to address efficiency and incentive effects while also addressing distributional concerns. This should have been supplemented by a strengthened income tax with a reformed land tax assigned to the local levels of government.

A GST was legislated by the political government in 1990, and implemented by governments of both parties throughout the decade-under IMF programs, with considerable technical assistance provided by IMF technical teams. A major effort to revamp the tax administration was also launched in 1999, and supported by the World Bank with a major loan, with yet another multi-year tax policy program supported by Georgia State University (see Martinez-Vasquez and Richter, 2008). Yet, at the end of the last decade of tax reforms, the tax/GDP ratio was reeling at under 9 percent. By most counts, this effort would be deemed to have been a failure.

It is essential to understand the causes for the failure of the tax reforms in evaluating what needs to be done in going forward. We ask whether the policy prescriptions, particularly with respect to the GST, were sound, and if so, what other reasons might explain the outcome. In particular, we focus on the incentives facing successive governments with periodic inflows of foreign assistance and capital (especially in the 1980s and then again after 9/11), the role of special interest groups-in particular a rentseeking bureaucracy - as well as the role of informality, and more recently the constraints faced within the context of a weakened center and resurgent provinces keen to score points in maximizing access to resources. Each one of these issues was raised in Ahmad and Stern (1991), yet the extent of the constraints involved was perhaps not fully appreciated at the time.

\section{Effective taxes and the reform of the sales tax, excises and customs duties}

The National Taxation Reforms Commission established in 1985 described the Pakistan tax system:

"as stated in our letter dated May 15, 1986 transmitting our interim report, the three basic maladies from which Pakistan is suffering at present are tax evasion, smuggling and corruption. These are interrelated and one feeds on the other."

\footnotetext{
${ }^{1}$ Letter from Chairman Qamar ul-Islam to the Finance Minister, December 31, 1986. Other members of the Commission included Industrialists: Syed Babar Ali, Haneef Adamjee; MNAs: Nawaz Khan Bugti, Gohar Ayub Khan and Sardar Assef Ali; Senator
} 
The Commission also referred to a complicated and archaic system of tax laws and recommended to the government that it begin to prepare to implement a VAT in the medium term. In particular, the Commission noted that the actual sales tax collection (1982-84) was a shade over 10 percent of the true potential that could be realized if there were no exemptions.

Based on the University of Warwick/LSE (ODA, ESRC and World Bank-financed) research program on tax reforms in developing countries (Pakistan, India and Mexico), Ahmad and Stern made submissions to the Commission. The tax/GDP ratio that had been 14 percent in $1980 / 81$, or close to the developing country average, had declined to 11.3 percent by 1985-a period of military rule (see Table-1). The system was heavily reliant on the taxation of intermediate inputs, largely collected at the import stage, leading to significant divergence of the true tax element in the price of final goods relative to the tax rates on these goods desired by policymakers. The cascading also led to considerable production distortions and discriminated against exporters. They also described the tax system as reflecting a colonial heritage, weak administration rife with rent-seeking that was incapable of financing the public expenditure levels needed in an independent Pakistan (Ahmad and Stern, 1991, p. 49).

Table-1: Pakistan's tax system in 1985 relative to other developing countries

\begin{tabular}{|c|c|c|c|c|c|c|}
\hline & $\begin{array}{c}\text { Pakistan } \\
\text { (1985) }\end{array}$ & $\begin{array}{c}\text { All } \\
\text { developing }\end{array}$ & $\begin{array}{c}\text { Very } \\
\text { Poor } \\
<\$ 349\end{array}$ & $\begin{array}{l}\text { Poor } \\
\$ 350> \\
<\$ 849\end{array}$ & $\begin{array}{c}\text { Middle } \\
\$ 850> \\
<\$ 1699\end{array}$ & $\begin{array}{c}\begin{array}{c}\text { Better } \\
\text { off }\end{array} \\
\$ 1700<\end{array}$ \\
\hline Customs & 5.5 & 5.0 & 4.9 & 6.6 & 5.3 & 3.9 \\
\hline Sales & 0.9 & 2.0 & 1.9 & 1.4 & 1.9 & 3.1 \\
\hline Excises & 3.0 & 2.0 & 1.6 & 2.2 & 1.9 & 2.2 \\
\hline \multirow[t]{2}{*}{ Income and Corporate } & 1.9 & 5.6 & 2.7 & 5.5 & 5.8 & 8.1 \\
\hline & 11.3 & 14.7 & 11.1 & 15.8 & 14.9 & 16.5 \\
\hline
\end{tabular}

Note: The tables are in terms of percentage of GDP and ranked by 1985 incomes per capita.

Source: Ahmad and Stern (1991) based on Tanzi (1987).

It is clear that the Pakistani tax system in the mid-1980s compared unfavorably to that in virtually all groups of developing countries-with very weak collections of sales and income taxes. The bulk of the revenues was

Akram Sultan; HU Baig (Finance Secretary); Hamid Habib (Export Promotion Bureau); Dr. Baqai (Planning Secretary) and Chairman CBR. 
generated by high and distortionary taxes on tradeables and productionparticularly import duties and production excises. These had negative impacts on production and exports, and unintended distributional implications.

\section{Effective taxes}

The cascading effect of the tax system was clearly apparent for sectors that were nominally not subject to tax or were subsidized. For instance, the effective subsidy on wheat was a third lower than intended. Further, a number of sectors were not taxed directly-either because the items were consumed by the poor or were largely exported. For instance, zero taxes were levied on bidis, cotton ginning, small scale cotton textiles, carpets and rugs, made-up garments, printing and publishing, rubber and footwear, pharmaceuticals, sports goods, surgical instruments and bicyclesyet the effective taxes on these sectors were quite significant. The cascading effectively negated the policy design, and created impediments for exports.

Table-2: Nominal and Effective Taxes on Selected Sectors

\begin{tabular}{|c|c|c|c|c|c|c|c|c|c|c|}
\hline Sector & Bidis & $\begin{array}{l}\text { Cotton } \\
\text { ginning }\end{array}$ & $\begin{array}{l}\text { Carpets } \\
\text { and } \\
\text { rugs }\end{array}$ & $\begin{array}{l}\text { Pharma- } \\
\text { ceuticals }\end{array}$ & $\begin{array}{l}\text { Foot } \\
\text { wear }\end{array}$ & $\begin{array}{l}\text { Sports } \\
\text { Goods }\end{array}$ & $\begin{array}{l}\text { Surgical } \\
\text { Instrs }\end{array}$ & $\begin{array}{c}\text { Printing } \\
\text { and } \\
\text { Publishing }\end{array}$ & Glass & Cement \\
\hline Nominal tax & 0 & 0 & 0 & 0 & 1.4 & 0 & 0 & 0 & 20.1 & 12.1 \\
\hline Effective tax & 6.5 & 2.5 & 9.1 & 16.8 & 7.3 & 6.7 & 5.5 & 8.0 & 40.0 & 27.1 \\
\hline
\end{tabular}

Source: Ahmad and Stern (mid-1980s for the NTRC), see Ahmad and Stern (1991) Table-6.4.

Recognizing that the tax system discriminated against exports, a system of compensatory export rebates was in force in three slabs-the highest being 12.5 percent which applied inter alia to carpets, footwear, sports goods and surgical instruments. As seen in Table-2, this overcompensated for the effective taxes on these sectors, and formed a pure export subsidy, as well as loss of revenues to the exchequer.

\section{Strategy for reforms}

Ahmad and Stern argued that the reform of the sales tax needed to be the centerpiece of the tax reforms in order to:

- Widen the tax base;

- Effectively increase revenues; 
- Avoid the cascading associated with the cumulative taxation of intermediate goods and raw material inputs;

- Provide an accurate basis for the calculation of refunds for exporters;

- Provide a basis for cross-checking of returns, and assist with the true estimations of the income tax liabilities in order to improve and strengthen income tax collection.

The options available at the time included a retail sales tax; retention of a manufacturing sales tax with fewer exemptions; and a VAT. While a retail sales tax and VAT are identical in terms of the revenue generated and the effects on prices, the former is relatively easy to avoid, especially in a developing country like Pakistan. The difficulty with the manufacturing sales tax is that it generates cascading, and does not provide a basis for enhancing income tax revenues, unless a refunds system is introduced-bringing it closer to a VAT, but without the full coverage of the latter.

The directions of reform suggesting that the indirect tax system should be differentiated on the grounds of efficiency or distributional considerations do not imply that multiple rates are needed for the VAT, or that there should be extensive exemptions. Consequently, a move to a VAT was recommended by Ahmad and Stern in a submission to the Taxation Reforms Commission, with the suggestion that a simple one- or two-rate VAT be supplemented by selected excises on final goods, as well as a strengthened income tax and property/land taxes for local governments.

Of course, since the mid-1980s, VAT has been adopted virtually universally $^{2}$ with major enhancements in revenue potential that has facilitated a shift away from distortive trade taxes in most cases. Comparable developing countries have managed to collect between 7 and 10 percent of GDP using VAT at rates in the 15 percent range.

\section{Design and Implementation of the GST}

\section{Design}

The analytical work of Ahmad and Stern in the mid-1980s also suggested welfare improving the directions of reform in raising additional

\footnotetext{
${ }^{2}$ The USA is the remaining major exception, but has a reasonable system of retail sales taxes at the state level. See Bird (2010) for a recent review of the VAT in federal countries, and Boadway (2010) for an analytical discussion of the options suggested by the Canadian experience.
} 
revenues. This was based on the changes in effective taxes-reflecting effects on households in different circumstances and on production incentives. The use of effective taxes abstracts from administrative difficulties-it is after all based on what is collected, and at the end of the day it reflects the combined effects of informality as well as inefficiencies in the administrative machinery. Thus, an additional rupee could be raised as easily by enhancements in the administrative capabilities as it would from raising the tax rates while keeping administration constant.

The analysis showed that the directions of reform would vary depending on the preferences of policymakers, and the "package" associated with treating a rupee to all citizens equally $(\varepsilon=0)$ would look very different from that if the weight given to the poorest households were to be increased (see Table-3). Thus, if a government were only concerned with the welfare of the poorest (almost Rawlsian maxi-min preferences), this would be equivalent to a high value of the inequality aversion parameter $\varepsilon$, or Atkinson index approaching 5 .

In Table-3 a commodity ranked 1, or relatively low, would not be as attractive a candidate for raising additional revenues as one ranked higherof the 13 groups, the highest rank would indicate the most attractive candidate to raise revenues. It is interesting that the commodity group "wheat" switches rank-if one were not concerned for the poor, it would be a good commodity on which to levy additional taxes, but if even moderate concern for the poor were entertained ( $\varepsilon=1$, say) it becomes the least attractive commodity to tax. Another commodity that switches rank in the opposite direction is "housing fuel and light," and becomes a better candidate for taxation as concern for the poor increases. 
Table-3: Pakistan: Welfare improving directions for reform (ranks for $\lambda_{i}$ ) with increasing concern for the poor $(\varepsilon)$

\begin{tabular}{lccccc}
\hline Commodities/ $\varepsilon$--inequality aversion & 0 & 0.5 & 1.0 & 2.0 & 5.0 \\
1. Wheat & 10 & 4 & 1 & 1 & 1 \\
2. Rice & 7 & 7 & 6 & 6 & 7 \\
3. Pulses & 8 & 5 & 3 & 2 & 2 \\
4. Meat Fish, Eggs & 13 & 13 & 13 & 13 & 13 \\
5. Milk and Products & 11 & 11 & 10 & 10 & 11 \\
6. Vegetables, fruits and spices & 12 & 12 & 11 & 11 & 9 \\
7. Edible Oils & 1 & 1 & 4 & 4 & 4 \\
8. Sugar & 3 & 3 & 5 & 5 & 5 \\
9. Tea & 5 & 2 & 2 & 3 & 3 \\
10. Housing, fuel and light & 2 & 6 & 8 & 9 & 10 \\
11. Clothing & 6 & 8 & 9 & 8 & 8 \\
12. Other foods & 9 & 9 & 7 & 7 & 6 \\
13. Other non-foods & 4 & 10 & 12 & 12 & 12 \\
\hline
\end{tabular}

Source: Ahmad and Stern (1991)

Notes: The welfare loss for commodity $i, \lambda_{i}$, represents the effects on all households (using Household Survey data on consumption, and estimated demand responses) of an increase in the tax on the $i^{t h}$ good sufficient to raise a rupee of government revenue. The $\beta^{h}$ are welfare weights on households, and $\varepsilon$ is the inequality aversion parameter ranging from 0 to 5 . A good ranked 1 would be such that a switch of taxation from it to any other good would increase welfare at constant revenue.

$$
\lambda_{i}=\frac{\sum_{h} \beta^{h} x_{i}^{h}}{X_{i}+\sum_{j} t_{j}^{e} \frac{\partial X_{j}}{\partial t_{i}}}
$$

Three commodity groups stand out with invariant rankings. The highest, under all permutations of the inequality aversion parameter, is the "meat, fish and eggs" category-consumed more or less exclusively by the well to do, such that switching taxation from any lower ranked commodity would be welfare enhancing. Similarly, "milk and products" remains an attractive commodity to tax-despite the lobbying efforts of the organized sector and multinationals. "Other nonfood items" comprising largely 
durables and the like remain attractive and retain a relatively high rank; although the rank is low at low levels of $\varepsilon$, reflecting relatively high own and cross-price elasticities. It is noticeable that the "clothing" group, which is in the middle of the range at low levels of inequality aversion, rises to $8 / 9$ with little variation. It is certainly not a sector that would be singled out for special treatment either on revenue, efficiency, or distributional grounds.

As mentioned earlier, the Ahmad-Stern analysis suggested that VAT should be imposed, with at most two rates-although preferably one for administrative reasons-together with selected excises to approximate the directions of reform for higher levels of $\varepsilon$-assuming that policymakers in Pakistan are quite concerned with the welfare of the poor, or at least profess to having the interests of the poor at heart.

\section{Implementation}

Although the (common) Government of India Act 1935 had assigned sales taxes on goods to state/provincial governments and by exclusion the sales taxes on services to the center ${ }^{3}$, the assignment was changed in Pakistan by the Constituent Assembly through the Pakistan General Sales Tax Act (March 31, 1948) that moved the sales taxes to the federal government. This was, however, a turnover tax and applied at each stage on dealers with an annual turnover of greater than Rs. 5,000, and led to considerable protest. In order to correct for cascading, the 1951 Sales Tax Act applied only to consumption. However, the manufacturing and trade of goods was also subject to sales tax by the Taxation of Goods Order, 1960. It is interesting that under the 1951 Act, officers of the Income Tax also exercised authority over the sales tax. Amendments made in the Sales Tax Act (under General Zia's Government) in 1981 and 1982 shifted the collection of sales tax to the Central Excise Department, which administered it as if it were an excise tax, notwithstanding the provisions of the 1951 Act. This shift had far-reaching consequences, even when GST/VAT was finally enacted, as the administration remained in the hands of excise officers who continued to treat it as if it were an excise duty. During the 1970s and 1980s, revenues from sales tax ranged between 0.9 and 1.2 percent of GDP, with a built-in-elasticity of around 0.9 .

${ }^{3}$ This split assignment of the base for the GST has been problematic in India as well. This is discussed further below. 
The 1973 Constitution explicitly assigned the sales tax on services to the provinces, as at that time there was no GST/VAT, ${ }^{4}$ and services were taken to mean largely sectors such as hair and beauty parlors. A GST was finally implemented in Pakistan in 1990, by a political government. Given considerable opposition, the nascent democratic government took the step of introducing the GST through an amendment of the earlier 1951 Act as part of the Finance bill, sidestepping debate. Yet the tax was opposed vigorously by the business community. The tax quickly ran into difficulties, and in response successive governments resorted to presumptive methods and fixed prices for determining GST liability, incomplete refunds, and denial of input-credits. The tax was administered by staff steeped in the production excise mentality, and subjected taxpayers to treatment that they had come to expect under the production excise setup.

In addition to the incomplete base of the tax at the outset, a key problem with the GST was the frequent changes made to the base by the Central Board of Revenue (precursor of the Federal Board of Revenue, FBR) through Sales Tax Notifications and Statutory Regulatory Orders (SROs) without reference to Parliament. This gave the FBR enormous power, and the law degenerated into whatever the FBR said that it was at any point in time.

It was recognized throughout the 1990s that the GST was not performing as it should in terms of revenue generation as well as its neutrality in terms of production and exports. By the late 1990s, it was clear that a major overhaul of the tax administration was needed. There were two options: (i) create a modern tax administration for the GST ${ }^{5}$, based on armslength self-assessment and audit; or (ii) undertake a full overhaul for all taxes and create an integrated revenue authority, along the lines of the Argentine model. The second option was chosen ${ }^{6}$ and supported by a large loan from the World Bank (around \$120 million over a period of 8 years).

Attempts were made in the early 2000s to address policy gaps concerning the GST, particularly with respect to the coverage of services. In the early years of General Musharrafs administration (1999/2000), provincial assemblies passed legislation enabling the central government to collect sales tax revenues on services on their behalf, respecting the constitutional

\footnotetext{
${ }^{4}$ However, this provision has been strengthened and reaffirmed in the $18^{\text {th }}$ Amendment, missing a chance to address weaknesses in the revenue assignments as concurrent responsibilities were removed.

${ }^{5}$ This is the typical model supported by technical assistance from the Fiscal Affairs Department (FAD) of the IMF.

${ }^{6}$ This was on the basis of a report by Mr. Shahid Husain, who had been a Vice President for Latin America in the World Bank.
} 
arrangements, but trying to make the best use of scarce administrative resources. In addition, the key sectors of banking and insurance, as well as telecommunications were subjected to an excise tax in GST mode-bringing in some of the main revenue sources into the tax net. Also, the coverage of the financial sector represented a move toward best practice-something that has eluded the European Union which had exempted this sector (among many others-typical of earlier VAT systems). ${ }^{7}$

As part of the restructuring of economic policy toward greater openness and making Pakistan a better place to do business, the government rationalized and reduced import duties in the expectation that GST revenues would more than compensate for the loss in tariff revenues. Prime Minister Aziz made a great show of "breaking the begging bowl" in terminating early and repaying a concessional IMF loan under the Enhanced Structural Adjustment Facility (ESAF) program.

But the expected gains in domestic revenues did not occur. The GST collections continued to decline (from a high of 4.1 percent of GDP) to almost 3 percent of GDP at the end of the decade-and that is after 10 years of tax administration reforms and a hike in the rate of the GST. The tax/GDP ratio also fell in tandem, to under 9 percent of GDP by 2009-one of the lowest in the world for a large and complex economy with a population approaching 180 million. Indeed, the performance of the GST also ranked towards the worst in the world, including for comparable developing countries in the region.

Table-4 shows the efficiency with which the GST operates for Pakistan in an international context. The C-efficiency index shows how effectively the base of the GST is utilized. Most developing countries (such as Sri Lanka, the Philippines and Turkey) are located in the 0.45 to 0.5 range. Advanced middle income countries such as Singapore and Korea are in the 0.6 to 0.7 range. The most efficient GST in the world (reflecting a streamlined new law and efficient administration based on self-assessment) is New Zealand with C-efficiency of 0.93 .

\footnotetext{
7 See Waerzeggers (2010) for the EU experience, and Poddar and Kalita (2010) for modern options for taxing the financial sector under the GST.
} 
Table-4: C-Efficiency of the VAT-Pakistan in International Context

\begin{tabular}{lccc}
\hline & Standard Rate & Revenue/GDP & C-Efficiency \\
\hline Pakistan (1990s) & 15 & & 0.39 \\
Pakistan (2005) & 15 & 3.4 & 0.30 \\
Pakistan (2009) & 16 & 3.1 & 0.27 \\
Sri Lanka & 15 & 6.7 & 0.47 \\
Philippines & 12 & 4.3 & 0.45 \\
Turkey & 18 & 7.1 & 0.48 \\
Lebanon & 10 & 5.1 & 0.50 \\
Jordan & 16 & 10.1 & 0.62 \\
& & & (with luxury excises) \\
Korea & 10 & 6.7 & 0.67 \\
Singapore & 5 & 1.8 & 0.63 \\
New Zealand & 12.5 & 8.9 & 0.93 \\
\hline
\end{tabular}

Had Pakistan achieved an improvement in its C-efficiency rate toward Sri Lankan levels (circa 2005, when Sri Lanka was afflicted by civil war), GST revenues would have approximately doubled. But this did not happen, and the C-efficiency continued to decline, as did overall revenues, despite an increase in the standard rate to 16 percent in 2008/9. The question is why.

Part of the answer relates to coverage. Of the 138,000 taxpayers registered in 2007, roughly 90 percent of the GST was paid by 3 percent of the taxpayers with an annual turnover above Rs.300 million.

\section{Political economy of the reforms}

Weaknesses in the legal framework combined with administrative constraints to result in a tax regime that raised more revenues than in the past (around 3 percent of GDP through the 1990s rather than the 1.2 percent with the old sales tax) but continued to operate very much like the old excise system. The CBR frequently determined the price at which the GST would be "calculated", together with ad hoc presumptive mechanisms designed to "preserve" revenues but which negated the design of the GST. The legal framework prevented full crediting of input taxation. Further, the ability of the CBR to vary the base at will through SROs without reference to Parliament gave them power to do "deals" with vested interests, and also provided tools for the powers that be to bestow favors and punish the personae non grata. 
In consequence, legal provisions prevented the GST from being the "pass-through" consumption tax that it was meant to be, and reinforced the "backward-shifting" such that the incidence of the tax fell back on the producers. In the context of considerable "informality" and a narrow tax base, this had the effect of further penalizing formal sector enterprises that happened to fall into the GST net. Note that a properly functioning GST, with full input credits to registered taxpayers, is the strongest instrument to address the "informality" problem. Those that are outside the GST net are input taxed-or exempt, like final consumers, they have to pay the tax. The benefits of a GST system become apparent when there is automatic and full crediting and rapid refunds as these become due, but are lost if there is backward shifting onto producers. Thus, the main beneficiaries of a GST system-particularly producers and exporters-became the main opponents of the Pakistani-version of the GST. Distrust of the GST fed on the distrust of taxpayers by the $\mathrm{CBR}$, and the administrative hurdles further compounded difficulties for taxpayers, in addition to creating fruitful opportunities for "rent-seeking" and further gaming on the part of taxpayers. At this stage, the phenomenon of dummy companies established to generate fake or "flying" invoices became well established.

It became clear to successive governments by the late 1990s, that administration remained a serious constraint. An option would have been to set up a modern administration for the GST, gradually extending it to other taxes. ${ }^{8}$ However, the government at the time went for the more ambitious strategy of modernizing the entire administration-within an overarching revenue agency mode1, following the example in Argentina. ${ }^{9}$ This should have involved an integration of domestic operations, as distinct from customs. It also involved an extension of self assessment to the VAT and other taxes, together with an information system capable of cross-checking information provided by taxpayers and suppliers. By extension, the information system should also be able to provide information on value added, hence a check on incomes generated. But the reforms did not result in a streamlined administration capable of administering a modern GST. Part of the reason relates to policy errors by the administration at the time, together with reduced incentives to carry out tax reforms as there was an influx of external funds in the post-9-11 era. But a great deal was to do with continuing tax administration weaknesses and a lack of incentives for the tax

\footnotetext{
${ }^{8}$ It normally takes around three years to set up a VAT tax administration from scratch (see Ahmad and Al-Faris, 2010).

${ }^{9}$ Following the advice of the former World Bank Vice President for Latin America, Mr. Shahid Husain, and his team. A similar exercise was undertaken in the UK around 2004, with the operations of the VAT that had been part of UK Customs and Excise were integrated with income taxes.
} 
administration to establish arms-length operations that would minimize the pervasive rent-seeking.

\section{Pervasive rent-seeking and tax administration reforms}

Despite the well-intentioned tax administration reforms supported by a mega-World Bank loan, the project by February 2008 (the penultimate year of the loan) was described as "unsatisfactory", or a failure. There was clearly no acceptance of the premises of the reform by the tax administration. Even though the name of the tax administration had been changed, and a new headquarters constructed-along with regional officesthere was co-habitation of income taxes and sales taxes at best. An integrated functional organization had not even been initiated by 2008, when the project was deemed unsatisfactory.

There was no conceptual design for the new information technology system, yet considerable sums had been spent to construct "in-house" a new IT system, rather than purchasing a system off-the-shelf as is the international norm. There was absolutely no sign of business process reengineering. Consequently, much of the IT support was in the form of recreating existing manual procedures, and its ability to work in the new and automated GST environment, particularly with respect to refunds and payments to taxpayers' bank accounts is still to be proved. The issue of processes and procedures cannot be divorced from the IT design and options, and recreating existing procedures-such as generating checks when payments can be made to bank accounts-merely replicates points of contact between the tax administrators and the public at which rent seeking is generally exercised.

\section{Vested interests}

The inherent incentives in a GST provide benefits to producers within a chain. However, few of the advantages of the GST were experienced during the 1990s, and the resort to presumptive mechanisms to raise revenues was particularly damaging-resulting in backwards shifting of taxes and breaking the GST chain. This accentuates the incentives for enhanced informality. The rent-seeking added to the costs of doing business. Formal sector enterprises were also disadvantaged by the phenomenon of "flying invoices", manufactured by dummy firms and provided to fake exporters-increasing the penalty of "formality."

Sensible policies to increase the attractiveness of Pakistan as a place to do business, such as a reduction in tariff rates, had the effect of putting further pressure on the formal sector, particularly textiles and sports goods, 
as they struggled with an ineffective refund mechanism-causing them to be severely disadvantaged in an increasingly competitive environment. The reduction in tariffs led to a shift in the revenue base that was to have been filled by an improvement in the operations of the GST. In keeping with the business-friendly approach, the shift to "self-assessment" was initiated. However, lacking an information system, or effective audit, the GST failed to perform as anticipated and revenues continued to plummet.

Moreover, in the post 9-11 environment, with the significant resumption of foreign assistance as well as other capital flows, the incentive on the part of the government to raise revenues to replace customs duties was reduced. With the capital inflows, there was also an incentive to hold the exchange rate, and this posed additional difficulties for the formal sector-particularly exporters, but also domestic sales as cheaper imports started flooding the markets. Recognizing the pressure on the formal sector, as well as the issues of fake invoices that discriminated against the formal sector and also led to revenue hemorrhage, the government went for the unusual step to "zero-rate" all transactions, including domestic sales, for the major exporting sectors-textiles, sports goods, leather products, surgical instruments, carpets and rugs. This was to avoid having to give refunds to exporters-since most of the supporting documentation was fake.

The "zero-rating", however, effectively exempted these sectors (since refunds were not made available for domestic producers)-and effectively broke the input crediting chain for the large part of the manufacturing sector and reintroduced cascading. The additional implicit taxation of exports was offset by an effective suspension of audit. While this was meant to be a temporary measure, it has remained in place since then. The noquestions asked self-assessment system operating in Pakistan generated widespread gains for the taxpayers, to the detriment of revenue collection. It is not surprising that the business and exporting sectors continue to oppose a move towards a proper GST-the most vociferous opponents being in the textile and dairy sector (the latter including major multinationals). Neither of these sectors ranks particularly high in terms of sectors that might be suggested for reduced taxation (and would not be singled out for special treatment on the grounds of efficiency or distributional considerations) (see Table-3 above). But they do form effective lobbies, along with other sectors, as noted by the Competition Commission.

The renewed cascading has also reintroduced the wedge between nominal and effective taxes that will have raised prices for consumers. However, it failed to raise the revenues expected under the tariff rationalization program. This also made the macroeconomic situation much more fragile and susceptible 
to shocks. Just such a shock arrived with the spiraling effects of the international petroleum and food price increases in 2007.

Despite the precarious macroeconomic situation, resort to inflationary financing that is paid for by the poor, and the agreements with multilateral donors under an IMF program, wide sections of the business community remain opposed to the reformed GST. Officials of the FBR strongly resist an integrated arms length administration, as this would limit the opportunities for rent seeking. Vested interests have hamstrung the GST, reinforcing trends from the 1990s. But why is the business community so insistent against a reform that should be in their interest? This is partly linked with the generation of information that could also be used to determine income tax liability. Equally important, the lack of credibility of the tax administration poses serious constraints, and successive governments since the 1980s have had difficulty in getting to grips with this challenge. Part of the problem is legal-the FBR has the power to amend and change the base of the tax without reference to Parliament-through the issuance of SROs. It continues to treat the GST as if it were an excise tax, with fixed price and presumptive regimes. Moreover, the refunds system is still not operational after 10 years of reform supported by the World Bank Tax Administration Reforms Project-although a new administration for the GST could have been set up from scratch in around three years. ${ }^{10}$ The power to grant exemptions suits the tax administrators as it provides a basis for bestowing favors, and appeasing the interest groups. Thus, the interests of administrators and the powerful vested groups reinforce each other.

There is yet another set of interests that is affected by the interplay between the administrators and the business community-this is represented by provinces that also display a sense of grievance and distrust concerning the administration.

\section{Provincial issues}

The abject performance of the revenue administration had another undesirable impact-that on provincial finances, exacerbating tensions and the "trust deficit" between them and with the federal government.

Following the start of the FBR modernization, in 2001, the federal government "persuaded" the provinces to legislate extensions of the GST to

\footnotetext{
${ }^{10}$ International experience suggests that a modern administration, including for the GST, can be set up from scratch in three years or so (Ahmad, 2010).
} 
services (on a service by service basis), and to delegate administration to the FBR. Of course, this heightened expectations that remained largely unmet.

A success story relates to key sectors such as telecommunications, and banking and insurance, that were brought into the GST net through the imposition of a federal excise tax in GST mode (i.e., with crediting of taxed inputs and crediting/payments of refunds to businesses using these services). This reform was a positive example of tapping a growing revenue base (telecommunications) within an integrated framework-even though the legislative authority remains provincial. Also subjecting banking and insurance to the GST permitted these sectors to also benefit from input credits-more important than the additional revenues generated. This is treatment is in line with international best practice, that puts Pakistan ahead of the EU, which had originally exempted the financial sector but now recognizes it to be desirable to bring these sectors into the VAT, but has been unable to achieve this (Poddar and Kalita, 2010). Once exemptions are granted, these become difficult to remove-something that also holds in countries more advanced than Pakistan.

\section{Provincial perceptions and the National Finance Commission (NFC)}

An influential World Bank report on the Pakistan tax system (Martinez-Vasquez and Richter, 2008), pointing to the evident problems with the tax administration, suggested that there is a significant tax gap with the GST, ${ }^{11}$ and that much of it is due to the poor administration of the tax on the service sector. They juxtaposed the share of services in GDP (around 58 percent) with the share of services in tax revenues (around 33 percent) to illustrate the tax potential of the GST on services. This was supplemented by a tax-gap analysis. ${ }^{12}$ In reality the share of services in GDP overestimates its share in the GST. This is because many services are purchased largely by businesses that will be entitled to credit or refund of any VAT charged on their purchases-and the net share of services is likely to be much smaller in the GST.

The World Bank report also argued that the FBR has "little incentive to collect these taxes or expand the base to other services,"13 given the small

\footnotetext{
${ }^{11}$ A more detailed presentation on the tax gap with the GST, presented by Mark Rider (2010) to the Federal Revenue Advisory Committee suggested that the estimate had been based largely on an estimate for the banking sector, and that deposits had been used as a proxy for the base. When a more rational estimate of the base is used, the estimate from the banking sector falls to about one tenth — or roughly what is currently being collected.

${ }^{12}$ Mark Rider and Roubina Ahmed, 2008.

${ }^{13}$ Martinez-Vasquez and Richter, 2008, p.71.
} 
collection fee and the revenues that have to be returned to the provinces. This encouraged the provinces, particularly Sindh, to begin to set up a provincial tax administration for the GST-ignoring the caveat by MartinezVasquez and Richter that provincial administration of the GST on services would likely lose revenues. As noted above, it takes countries an average of three years to establish a VAT administration from scratch. For a province like Sindh to initiate this process for a GST on services (the most difficult part of any GST, given the mobile bases and hard to define "place of supply rules") would take much longer-without considering the arrangements for cross-crediting with other provinces and sectors (including the federal component on goods).

Another study in the World Bank series (see Bah1, Wallace and Cyan, 2008) suggested that the share of Sindh in the GST is around 58 percent. This was based on an incomplete sample and left out the major taxable services.

Table-5: GST revenues from selected services (Rs. Million)

\begin{tabular}{lrrrrr}
\hline & Punjab & Sindh & KP & Bal & Total \\
\hline Hotels & 1,343 & 514 & 54 & 17 & 1,929 \\
Travel agents & 240 & 648 & 4 & 3 & 896 \\
Advertisements & 49 & 668 & 0 & 1 & 717 \\
Courier and clearing agents & 42 & 908 & 0.2 & 0.4 & 651 \\
Total & 1,694 & 2,457 & 60 & 20 & 4,231 \\
Percentage & 40 & 58 & 1.4 & 0.5 & \\
\hline
\end{tabular}

Source: Bah1, Wallace and Cyan (2008), p. 261

This perspective was also reiterated in another FBR assessment (possibly using the same incomplete data) presented to the National Finance Commission for a subset of services that the share of Sindh was close to 70 percent. It was not clear what the components of the FBR estimate included-especially whether the headquarters issue had been addressed carefully (many of the corporate headquarters are in Karachi (including for some banks and it is the main port). Relying on headquarters and location of importers and shipping handlers is misleading, since their activities are as much related to operations in other land-locked provinces. In fact the GST on services amounts to roughly Rs.63 billion, of which the items quoted in from Table- 5 form around 12 percent-and much of the revenues attributed to Sindh are from advertisement, travel related and clearing agents-all reflecting activities throughout the country. 
Indeed, the data for 2008 and 2009 from the FBR present a more complete picture (see Table-6)

Table-6: Taxation of services (including telecommunications, banking and insurance)

\begin{tabular}{lcc}
\hline Services & $\mathbf{2 0 0 8 / 9}$ & 2009/10 (to April) \\
\hline Total & 63.1 & 52.1 \\
Telecoms & 50.1 & 37.0 \\
\multicolumn{1}{c}{ of which phones } & 6.0 & $\ldots$. \\
Hotels & 1.7 & 1.4 \\
Banking & 3.0 & 3.9 \\
Insurance & 2.9 & 3.7 \\
Couriers & 1.1 & 1.7 \\
Stevedores & 1.0 & \\
\hline
\end{tabular}

Source: Federal Bureau of Revenue.

A juxtaposition of the charge that the FBR was deliberately disinterested in collecting the GST on services, together with the supposition that there is a great deal of additional revenues from the sector, particularly financial services, unfortunately exacerbated the "trust deficit" between the federation and the provinces, particularly Sindh, just at the time that the NFC discussions began in 2009. This quickly became a political issue, and getting a "fair" share, i.e., close to 70 percent, of the GST on services (believed to be potentially Rs.300 billion, or an additional 2.5 percent of GDP) became part of the electoral campaign of the party forming the Sindh Government, as it pressed for a larger share of a "growing resource base."

The NFC reiterated the right of the provinces to levy and collect GST on services-this was further strengthened in the $18^{\text {th }}$ amendment to the Constitution-despite the fact that no province, neither the most advanced Punjab nor Sindh, has the ability to implement any kind of crediting or refunds mechanism needed under a GST. In addition, a mechanism would need to be established to "clear" claims on interprovincial transactions-particularly the issue of refunds that has been a problem for the Federal Government. It would take at least three to five years to set up a GST administration from scratch. Moreover, taxing services is the most complicated part of a GST-given that in many cases it is hard to define what a service is, and to determine precise place of supply rules. 
The NFC decision on GST collection is clearly not operational during the life of the current award. While the NFC failed to make it explicit, the revenue-sharing estimates were based on the assumption that there will be an integrated GST to generate additional resources envisaged over the medium-term. With a provincial administration of the GST, the warning by Martinez-Vasquez and Richter (2008) needs to be reiteratedthere is likely to be a loss in current revenue collections.

In the case of telecommunications, the major sector for service revenues, the headquarters of the largest companies are in Islamabad. Detailed transactions data show that whatever measure of the base is chosen-calls made, calls received, billing of customers and numbers of handsets, the distribution across provinces is roughly in line with aggregate consumption patterns across provinces (see Table-7). Moreover, for the most recent full year for which data are available, input credits on account of telecommunications claimed by other sectors (including businesses in Sindh and other provinces) was roughly 8 percent-or just over Rs.3 billionalmost equivalent to the amount "estimated by Bahl et al. (2008) for the total collections from the GST on services.

The heightened expectations of Sindh concerning a 50 to 60 percent share in the GST on services if it collects the tax are optimistic. Indeed, the Sindh bill presented to the provincial assembly is in the form of a final point sales tax, without crediting or refunds. As we shall see below, this has the potential to recreate the distortions that the GST was designed to eliminate, and more importantly could lead to tax "exporting" to other provinces if applied in an indiscriminate manner, with considerable scope for retaliatory behavior by other provinces to the detriment of all. This can only result in an unfortunate "beggar-thy-neighbor" tit for tat. 
Table-7: Provincial share in consumption of services by households 2007/08

\begin{tabular}{lccccc}
\hline & $\begin{array}{c}\text { Number of } \\
\text { Households }\end{array}$ & $\begin{array}{c}\text { Monthly } \\
\text { Expenditure } \\
\text { on Services } \\
\text { per household }\end{array}$ & $\begin{array}{c}\text { Annual } \\
\text { Expenditure }\end{array}$ & $\begin{array}{c}\text { Provincial } \\
\text { Share }\end{array}$ & $\begin{array}{c}\text { Population } \\
\text { Share }\end{array}$ \\
\hline Punjab & $\mathbf{( 0 0 0 )}$ & $\mathbf{( R s . )}$ & (Billion Rs.) & $\mathbf{( \% )}$ & $\mathbf{( \% )}$ \\
Sindh & 14,589 & 3,535 & 618.9 & 60.39 & 57.36 \\
K-P & 5,872 & 3,454 & 243.4 & 23.74 & 23.71 \\
Balochistan & 2,916 & 3,825 & 133.8 & 13.05 & 13.82 \\
Total & 1,062 & 2,260 & 28.8 & 2.82 & 5.11 \\
\hline
\end{tabular}

\section{Issues involved with a provincial GST on services}

In keeping with recent NFC and the Constitutional Amendment, there is no debate that the revenue from the VAT on services will be returned in entirety to the provinces-this includes items presently covered under the federal excise duty (FEDS) in GST mode on services. The FEDS will be replaced by the GST, and will remove services entirely from federal jurisdiction, except those assigned under the constitution relating to taxation of terminal services (transportation). As part of the ongoing GST reforms, attempts are being made to block loopholes and all services will be covered, except perhaps for a 'negative listing' of a few sensitive items (such, perhaps, as funeral services) that will be excluded from tax in all provinces.

Under a modern legal perspective, 'goods' would be defined consistent with Pakistani case law, and 'services' then as anything that is not a good. This would simplify the legal framework in line with international best practice, and close the loopholes that exist under the current schedular approach to listing individual services. This approach would be facilitated by an integrated and common administration for the GST that provides services for the federal and provincial governments. A common administration also minimizes the need to specify the place of supply rules for each service.

The alternative, if provincial administrations could be set up to operate the GST-particularly on services-would be to define each service, with associated place of supply rules, and mechanisms to deal with crossprovincial transactions. This would be a difficult and lengthy exercise and considerable thought and agreement would be needed to avoid the issue of 
inter-provincial versions of "flying invoices", called "invoice sightseeing" in Brazil. ${ }^{14}$ There are always dangers that provinces with geographical advantages (e.g., ports) may be able to export taxes to other provinces, or that those with weak administrations might generate excessive input refund claims against the others. Under present conditions, this is a nonstarter, given existing administrative capabilities. It would also require considerable consultation and agreement between provinces to go down this route and assurances that one province would not unfairly take advantage of the others. We discuss these issues below in examining a possible compromise arrangement with elements of the extreme cases of central or provincial administrations-suggesting a hybrid approach for the current NFC award period.

\section{How to implement a provincial GST on services}

Very few countries seek to identify the revenue from some particular items for allocation to a particular level of government-although that had been a tradition in the British Empire, and in the 1935 Government of India Act, sales taxes on goods were assigned to the states (provinces). As mentioned above, this arrangement was reversed in Pakistan. Similarly, with a split jurisdiction over bases, with goods under federal purview as in Pakistan, Australia has chosen to apply a single VAT on goods and services and return the entire revenue collected to the states (provinces)—see Searle (2010).

There are difficult issues related to the definition of goods and services, and these generate a great deal of case work and complications in the legal framework (see Box 1). Pakistan is atypical in assigning services to the provincial level, and in addition to the problems that are evident in India, there are difficulties in deciding how to apply the tax and determine the revenues to be shared.

\section{Determination of the base}

Ultimately, the GST is intended to be a tax only on final consumption, not on business use. Thus, one might interpret the "VAT revenue from services" as that part of total GST revenue that reflects the final consumption of services-In gauging the likely revenue yield from a

\footnotetext{
${ }^{14}$ Reference to the Brazilian model is quite useful in this context. The Brazilian VAT is very complex with overlapping bases, and considerable difficulty in dealing with crossstate (provincial) transactions. Services are subject to a local final point sales tax, with considerable cascading effects. There have been many proposals to reform the system, emanating from the 1990s, but successive governments have not been able to deal with the vested interests that have coalesced around the current inefficient framework (For a review of the Brazilian system, see Varsano (2003)).
} 
fuller inclusion of services under the GST in Pakistan, it should also be noted that many of the 'big ticket' services items (notably telecoms) are already taxed under the FED.

Another possibility would be to treat the provincial sales tax as the gross GST that is charged on sales of services. This is close to the proposed legislation by Sindh, but it ignores the GST on inputs that service providers will take as a credit. It would also give away more of the GST to provinces than actually collected from the service sectors.

A third possibility is the net GST charged by service providers. Box 1 provides a simple example illustrating these options-- which can give quite different views as to the revenue to be allocated.

\section{Box 1: The revenue from services: An example}

Consider a construction service company that makes sales of Rs. $100 \mathrm{~m}$, of which Rs. $80 \mathrm{~m}$ are to businesses and Rs. $20 \mathrm{~m}$ to consumers. Suppose it has inputs of Rs. $60 \mathrm{~m}$, and the VAT rate is 10 percent.

Final consumption of construction services is in this case Rs. $20 \mathrm{~m}$, so that on the consumption-based view "GST revenue from the sector" is Rs. $2 \mathrm{~m}$. Focusing on output GST, or a final point sales tax, on the other hand, it is Rs. $10 \mathrm{~m}$; and focusing on net GST it is Rs. $4 \mathrm{~m}$.

An advantage of the consumption-based view is that it ensures that the total revenue attributed to services does not exceed the total revenue raised by the GST. The two other allocation rules would allocate to the provinces more revenue than the GST actually collects! Denial of input credits could also generate cascading and retaliatory behavior by other provinces.

\section{Sindh proposal to implement a final point sales tax}

The proposal of the Sindh government to operate a final point sales tax on all services, with one or two exceptions, without refunds or input credits, could seriously damage the GST in Pakistan.

It would, for a start, breach the basic tenet of providing credits for all taxed inputs-reintroducing cascading and distortions. This would move the clock back 20 years, and could seriously damage the competitive position of Pakistani firms.

In addition, Sindh could begin to export the tax to other provinces, 
for instance by imposing a non-refundable tax on importers and courier agencies-most of which are located in the port city of Karachi. This could be seen as an import duty collected by Sindh, particularly on imports by other provinces, with damaging effects on inter-provincial cooperation, to say nothing about the impact on producers and exporters. ${ }^{15}$ Again, this would negate the spirit of the reforms to enhance the business climate over the past 10 years, and could risk retaliatory behavior by the other provinces. Baluchistan, for instance could reduce the provincial sales tax to zero in order to attract the more mobile bases, and to encourage use of the competing port of Gwadar. Other provinces could retaliate in kind, including in other, non-tax related, areas. This could generate a "race to the bottom" and a damaging competitive federalism with severe consequences for the federation (see Breton 2002).

With a coordinated approach to a GST, dangers of the "race to the bottom" are reduced, especially if there is agreement on the range within which rates might be set, albeit not eliminated. As long as incentives remain to increase revenues in one province at the expense of others, as would be the case with strategic location, the possibility of game-play cannot be eliminated, and solutions are likely to be of a short-term nature. In what follows, we seek such a short-term solution to be able to consolidate the policy and administrative reforms for long enough to stabilize the economy, e.g., during the life-time of the present NFC award.

The next NFC remains the forum for addressing the instability and unsatisfactory nature of the present dispensation, following which a more stable equilibrium could be sought. This should give provinces a more assured share of total revenues, and also some control over "rates" at the margin, in order to make the assignment a more effective source of ownrevenues. The options include dual-GSTs on the Canadian model. Even more appealing could be the Italian IRAP (Imposta Regionale sulle Attività Produttive), an origin-based GST with rates determined by the region that sits on the central GST base, and can be administered by a single administration. Autonomy of administration is indeed less important than autonomy over setting rates (see Ahmad and Brosio, 2009) in achieving regional objectives as well as accountability.

\footnotetext{
${ }^{15}$ This is reminiscent of the octroi, or cascading tax on movement of goods from one local government to another. One of the most farsighted reforms of the Musharraf administration was the abolition of the octroi for a share from the GST going directly to local governments. While this disappointed the local governments, given that the performance of the GST has not lived up to promise, it also removed a tax handle under their control. The absence of own-source revenues for local governments was perhaps the greatest weakness of the decentralization process initiated by Musharraf.
} 


\section{Which agency should administer the provincial GST?}

There are three sets of options: from a single administration for an integrated GST to sole provincial administration for the GST on services.

\section{A single agency for the federal and provincial governments}

\section{a. Existing split bases}

To have a reformed integrated agency collect more efficiently, a tight new law without loopholes and in an arms-length manner may be the most efficient way to raise additional revenues. It may also be the most business-friendly option, as it then minimizes the dangers of multiple rentseeking agencies, or imposition of additional non-creditable taxes. The issue then becomes one of how the monies are to be distributed across provinces. This is discussed below.

\section{b. Consolidated bases}

If the base is extended to cover goods, then the single agency can be designated also to collect the full provincial GST on an origin basis, on the Italian IRAP model. This involves the specification of a range within which provinces can set their tax rates, and gives greater flexibility and accountability. Again, only one tax return is needed. The control over the rates at the margin provides greater accountability for the provincial government and constitutes true own-source revenues, even if the administration is shared.

\section{Complete provincial administration}

\section{a. Existing split bases}

It is unlikely that the separate administration of split bases will ever be satisfactory, especially when the most complicated part of the GST (on services) is assigned to the sub-national level. This will require the full legal definition and specification of place of supply rules-this is not done in the existing GST law, and is only partially needed for the integrated model proposed. Even in the Indian context, where the provincial administrations operate the GST on goods, the GST task force commissioned by the recent NFC recommended that the base be consolidated and the legislation simplified in the run up to the next NFC (Indian NFC, 2009).

If provincial administrations are set up, the treatment of the GST on interprovincial transactions will need to be addressed-this is not a simple matter. 


\section{a. Consolidated bases}

Setting up a full provincial administration for the GST from scratch, with the full panoply of functions, including audit, information systems, crediting and refunds, will probably make sense if the base is changed to one that covers both goods and services. Again, the issue of the crossprovincial transactions has to be addressed

In case a decision is made to move to provincial GST administrations in all provinces, work would have to begin on a 5 -year plan to do so, along with mechanisms to address the cross-provincial issues. In the interim, it is clear that only modest moves towards a hybrid solution are possible.

\section{Hybrid solution}

The hybrid approach distinguishes between those services that do not significantly affect other sectors, or provinces, in terms of credits or refunds, and others that do. The former have to be carefully defined to ensure that other provincial interests are not affected. But provincial administration by one or more provinces for these services is possible without damaging the GST. Within the remaining set of services, that needs input credits and generates the need for credits for businesses, is the largest revenue earner-telecommunications. We thus treat the three elements of the hybrid solution separately.

\section{a. Stand alone services}

Just as one is able to peel off federal services, provinces could agree on the list of stand-alone services that would effectively be exempted or taken out of the GST net. Taxpayers in these sectors would not be able to claim input credits, nor would other sectors be able to claim credit for purchases of these sectors. These sectors would effectively be input taxed from the GST perspective.

There is considerable leeway for a province to declare a service as "stand alone", however care needs to be taken not to impose a final point sales tax on items that affect inter-state commerce, such as stevedores, shipping clearing agents and courier services. To do so would attract retaliatory behavior by the other provinces.

Some services such as construction businesses, architectural or accounting firms could in principle be subjected to a final point sales tax without affecting other provinces. But it may not be in the interest of a 
province to go this route, as it would severely disadvantage these sectors in the concerned province, say Sindh. First, they would be denied input credits, which may be significant in some cases, especially construction, and architectural firms. Secondly, registered businesses purchasing these services from those in Sindh would not be able to claim the sales tax as input credit. This is likely to induce a shift in these relatively mobile services to a more business friendly environment that applies the GST fairly. In this case, the imposition of such a tax on mobile bases would be self defeating. If, in order to offset the absence of input credits the final point sales tax is reduced, it may defeat the revenue generation objective, and Sindh may do better by allowing these services to be administered centrally and the revenues shared according to a fair and objective mechanism.

In other cases, such as chains of hotels with a presence in all provinces, significant input credits are required. If one province moves to a final point sales tax, an apportionment will need to be made by a central tax administration to ensure that purchases for the hotels in Sindh are not claimed against sales in other provinces. This is feasible, but will require administrative complexities and a stress on the federal tax administration.

The simplest items on which the final point sales tax can be levied are those such as restaurants, haircuts and beauty parlors. These may, in many cases, fall below the relevant GST registration threshold, and in these cases, the final point sales tax would be an attractive addition to the GST. Indeed most GSTs have a special treatment for small sector businesses that fall below the threshold.

There is an additional complexity on account of what is to be shared across provinces. If Sindh collects revenues from certain "stand alone services," and other provinces authorize FBR to collect taxes on these services on their behalf, then the revenue collected from these services should not be allocated to a pot from which Sindh draws its shares. A separate sharing mechanism would then have to be agreed by the other provinces.

\section{b. Services requiring input credits or forming inputs into other sectors}

The remaining services (other than telecommunications) have to be administered by the FBR under the integrated GST, because of the need for input credits-supplemented by audit. If the remaining services are subject to provincial administration, this would lead to a denial of input creditsleading to a contradiction, and these would inappropriately be treated as "stand alone" services. 
The amounts collected should be put in a fund for distribution to the provinces. The distributional issue is discussed further below.

\section{c. Telecommunications}

Much of the discussion relates to an acceptable treatment for telecommunications-the main revenue earner. A split arrangement whereby the FBR administers the input credits and claims against the telecommunications sector, whereas the taxes generated go directly to the accounts of the provinces on an agreed basis-would effectively "split" the administration and "collection" functions. If the basis for the distribution can be agreed, e.g., calls made and/or received, the telecommunications companies could make the tax payments directly to the provincial treasuries.

Thus, if the bulk of the sales tax on services can be "distributed" across provinces on an objective basis, the problem for the allocation of the rest becomes easier.

\section{Distributional issues}

The distributional issues with a major tax reform generally involve balancing the interests of the richer regions that generate the revenues with those of the poorer regions that lack adequate revenue bases. The ideal opportunity would have been to use the NFC award on transfers to supplement and cement the arrangements on the distribution of taxes. Given that this was not done, the distributional issue has to be defused by moving most of the issues off the table-such as an agreement between the provinces to deal with telecommunications on a rational basis.

For the remaining services, the distribution of net revenues could be on the basis of aggregate consumption-as seen in Table-7, this is the criterion that would be used with a destination-based GST, and would allocate the bulk of the GST on services to the Punjab. Alternatively, some approximation of an origin basis could be sought at an aggregate level.

A transaction-by-transaction division is neither feasible, nor desirable. It would place incredible burdens on taxpayers to identify the sector to which sales are made as well as the province. It would be very hard to generate an audit trail and cross verification of information, especially if multiple declarations are involved and several limited audit capabilities.

A more feasible alternative is for the telecommunications companies to make one return, with aggregate information on sales. Similarly, a single 
return would be needed for the "other services" category, with distribution according to macro-criteria. There is no ambiguity involved in the case of stand-alone services subject to provincial taxation, but even the provincial audit would benefit from links with the overall database being generated by FBR on global transactions, including imports, and use of electricity and other capital spending, cross-matched by taxpayers.

If telecommunications issues are solved, the distribution of the remaining sales tax on services becomes manageable-the difference between the 50 percent share assigned by the NFC for the tax origin factor, and the share that results from the consumption basis is small, even for Sindh. It may be feasible for the federal government to indemnify Sindh and Baluchistan (the other province likely to lose as a basis of the distribution according to the consumption criterion. This indemnity should be for a limited period, e.g., the life of the current NFC award, pending a more stable outcome on the sharing of the GST base.

\section{Incentives and stability of the hybrid solution}

While the hybrid solution is workable, it cannot be a permanent arrangement. For a start, some of the provinces, Sindh in particular, are not likely to get as much in the way of revenues in the short-to-medium term as had been expected, and this may cause political difficulties. Attempts by Sindh to go the final sales tax route on services that affect other provinces could generate a "race to the bottom."

Moreover, the solution would become feasible only if the federal government indemnifies some of the other provinces, again for shortfalls against expectations. But, in the face of more stringent resource constraints, this is unlikely to be tenable over the longer term.

It will then become imperative to revisit the revenue assignment together with the design of an equalization transfer mechanism at the next opportune moment-the next NFC award. But for that to be feasible, there should be significant technical inputs and analyses of the alternatives-to avoid having to make decisions by the seat of the finance minister's pants, as seems to have happened in the past. 


\section{Conclusions}

Much of the difficulty with the GST reforms in the past twenty years has been the poor design that has led to the tax being administered like an excise, with the administration having discretion to determine the base. The backward shifting, together with the rent seeking by the administration, have led to a situation where the groups in society that would benefit most from the GST-the producers, exporters and traders-oppose it strongly.

It is also not surprising that the tax administration sees the integration of the inland-revenue and arms-length operations as effectively reducing their personal income generation, and any number of court cases are underway to stop the reforms.

In the background, the poor revenue performance has also affected the provinces, and their resentment boiled over in the discussions leading to the National Finance Commission awards in 2009-with the Ministry of Finance (MOF) unable to present or cement a reasonable deal on the administration of the GST and supplemented by an equalization scheme. Rather, by separating the two issues, the MOF effectively lost control over both, whereas a joint solution would have been a Pareto-improving outcome. This has been the experience with major tax reforms in the pastas in China and in Mexico.

In sum, splitting the base of the GST by sectors, given the perspective of the 1930s style sales tax, is not very sensible, and the Pakistani formulation is more unstable than the assignment of GST on goods. As in India, it may be best to reexamine the assignments, as suggested by the Indian NFC for the medium term, to consolidate the revenue bases, simplify the legislation, and move towards a system of dual GSTs with both levels of government having joint-occupancy of the revenue bases. 


\section{References}

Ahmad, E., and Stern, N. (1991). Theory and Practice of Tax Reforms in Developing Countries. Cambridge University Press.

Ahmad, E. (2010). Design of a VAT for the GCC Common Market. In Ahmad and A1-Faris (Eds) Fiscal Reforms in the Middle East: VAT for the GCC, Edward Elgar.

Ahmad, E. and A1-Faris, A. (2010). Fiscal Reforms in the Middle East: VAT for the GCC. Edward Elgar.

Ahmad, E. and Brosio, G. (2009). Political Economy of Tax Assignments in Latin American Countries: Tax Autonomy versus Earmarked Revenues. National Tax Association, $100^{\text {th }}$ Anniversary Proceedings, National Tax Journal, 191-205.

Bah1, R., Wallace, S., and Cyan, M. (2008). Pakistan: Provincial Government Taxation. Working Paper Series, The World Bank and Georgia State University.

Bird, R. (2010). Central and Subnational VATs in Developing Countries. In Ahmad and A1-Faris (Eds) Fiscal Reforms in the Middle East: VAT for the GCC, Cheltenham, UK: Edward Elgar.

Boadway, R. (2010). The Design of VAT for Multilevel Jurisdictions: Lessons from Canada. In Ahmad and A1-Faris (Eds) Fiscal Reforms in the Middle East: VAT for the GCC, Cheltenham, UK: Edward Elgar.

Breton, A. (2002). An Introduction to Decentralization Failure. In Ahmad, E., and Tanzi, V. (Eds.), Managing Fiscal Decentralization, London and New York: Routledge, 31-45.

Government of Pakistan (1986). National Taxation Reform Commission, Final Report, Islamabad.

Martinez-Vasquez, J. and Richter, K. (2008). Pakistan: Tax Policy Report Tapping Tax Bases for Development. The World Bank.

Poddar, S., and Kalita, J. (2010). Treatment of Financial Services under a GCC VAT. In Ahmad and A1-Faris (Eds) Fiscal Reforms in the Middle East: VAT for the GCC, Cheltenham, UK: Edward Elgar. 
Rider, M., and Ahmed, R.A. (2008). Pakistan's Tax Gap: Estimates by Tax Calculation and Methodology. The World Bank and Georgia State University.

Searle, B. (2010). VAT, Revenue-Sharing, and Intergovernmental Transfer Design: The Australian Experience. In Ahmad and A1-Faris (Eds) Fiscal Reforms in the Middle East: VAT for the GCC, Cheltenham, UK: Edward Elgar .

Tanzi, V., (1987). In Newbery, D., and Stern, N. (eds.). Theory of Taxation for Developing Countries. Oxford University Press for the World Bank.

Varsano, R. (2003). Tax Reforms in Brazil. The Long Process in Progress, BID, Rio de Janeiro.

Waerzeggers, C. (2010). The European VAT and the Common Market Framework. In Ahmad and Al-Faris (Eds) Fiscal Reforms in the Middle East: VAT for the GCC, Cheltenham, UK: Edward Elgar . 
